GRIPS Discussion Paper 15-23

\title{
Bringing the Central Bank into the Study of Currency Internationalization: Monetary Policy, Independence, and Internationalization
}

\author{
Hyoung-kyu Chey \\ Yu Wai Vic Li
}

February 2016

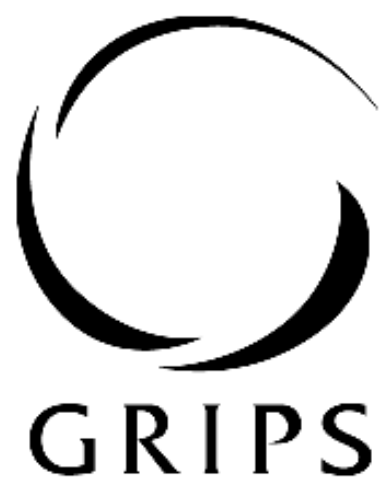

National Graduate institute FOR POLICY STUDIES

National Graduate Institute for Policy Studies

7-22-1 Roppongi, Minato-ku,

Tokyo, Japan 106-8677 


\title{
Bringing the Central Bank into the Study of Currency Internationalization: Monetary Policy, Independence, and Internationalization
}

\author{
Hyoung-kyu Chey ${ }^{*}$ and Yu Wai Vic Li ${ }^{* *}$
}

\begin{abstract}
Despite the central bank's crucial position in the economy, as the issuer of the currency and the body responsible for monetary policy, its preferences regarding currency internationalization and its roles in that process have rarely been analyzed in the literature. This study attempts to fill this critical gap by bringing the central bank into the study of currency internationalization. A conventional understanding of currency internationalization is that it tends to reduce monetary policy autonomy, which implies a natural tendency of the central bank to oppose it. This study shows, however, that currency internationalization does not necessarily reduce the central bank's monetary policy autonomy, and may in fact even strengthen it. It shows that currency internationalization is likely to strengthen the central bank's independence as well. Based on these findings, this study argues that a central bank with weak monetary policy autonomy and low independence is more likely to support the internationalization of its country's currency. These arguments are empirically verified, mainly by in-depth analysis of the case of the People's Bank of China and the renminbi.
\end{abstract}

Key words: Central bank independence, currency internationalization, international currency, monetary policy, People’s Bank of China, renminbi internationalization

\footnotetext{
* Corresponding author, Associate Professor, National Graduate Institute for Policy Studies, 7-22-1 Roppongi, Minato-ku, Tokyo 106-8677, Japan, email: hyoung-kyu@grips.ac.jp. ** Assistant Professor, the Hong Kong Institute of Education, 10 Lo Ping Road, Tai Po, Hong Kong SAR, email: vicliyw@ied.edu.hk. We wish to thank Eric Helleiner, Justin Robertson, Paul Commack, Michael Marking and seminar participants at the Bank of Korea for their helpful comments, and those who participated in the interviews for kindly agreeing to do so. Hyoung-kyu Chey is grateful as well to Stefan Angrick for his excellent research assistance, and to the Bank of Korea for offering him a visiting scholar position during August and September 2015. This study was supported by JSPS KAKENHI Grant Number 26380206; by a 2014/5 Policy Research Center of the National Graduate Institute for Policy Studies research project grant; and by the Hong Kong Research Grant Council under the Early Career Scheme fund (project number: 28402114).
} 


\section{INTRODUCTION}

Since the outbreak of the 2008 global financial crisis (hereafter, the GFC), tensions in the international monetary system have intensified - as skepticism over the status of the US dollar (hereafter, the dollar) as the dominant international currency has risen, as concerns about the sustainability of the euro have increased, and as the internationalization of the Chinese renminbi (hereafter, the RMB) shown impressive progress. Reflecting these turbulent changes, the political economy research on currency internationalization (hereafter, CI) has also grown substantially in recent years. ${ }^{1}$ Despite this the development of political economy theories of CI is still at an early stage, however, and a number of salient issues remain to be addressed.

The preference of the central bank regarding CI is one such issue. While the preferences of private interests, such as financial institutions and non-financial corporations, have been examined by a few studies, ${ }^{2}$ the central bank has rarely been spotlighted in the analysis of CI. This lack of concern with the central bank's preferences is quite surprising given that institution's pivotal position in the monetary and financial system. The central bank is the issuer of the currency and is in charge of monetary policy, and therefore also acts as the 'lender of last resort' in a crisis. The central banks in most major countries have in fact played leading roles in the recoveries of their economies from the GFC. Moreover, the US Federal Reserve (hereafter, usually the Fed) acted as a global lender of last resort during the crisis, providing dollar liquidity to foreign economies through currency swaps with them. The central bank is thus in a critical position in which it can have considerable influence on the internationalization of its country's currency, by either promoting or hindering it. And recent economic history studies (Eichengreen, 2011; Eichengreen and Flandreau, 2012) demonstrate that the Fed did in fact play a crucial role in the rise of the dollar as an international currency in the early twentieth century.

The neglect of the central bank in the study of CI might be attributable to the perception of the central bank as a technocratic public agency pursuing public interests. However, the central bank is also inherently a political actor-just like any other public agency-that wishes to maximize its own institutional interests along with the interests of the public. And CI can affect its core institutional interests, such as its monetary policy autonomy and independence. The central bank thus does hold particular preferences regarding the internationalization of its country's currency.

Against this backdrop, the present study brings the central bank into the study of CI by addressing its preferences related to that process, thereby ultimately highlighting the salience of domestic politics in it. The preferences of the central bank are analyzed by examining, among other things, how CI impacts its two core institutional interests, monetary policy autonomy and independence-respectively defined in this paper as the

\footnotetext{
${ }^{1}$ See, for example, Bowles and Wang (2008), Chey (2012, 2013, 2015), Cohen (2009, 2012a, 2012b, 2013, 2015), Cohen and Benney (2014), Germain and Schwartz (2014), Helleiner (2008), Helleiner and Kirshner (2009, 2014), Helleiner and Malkin (2012), Johnson (2008), Katada (2008), Kirshner (2008, 2014), Liao and McDowell (2015), Ly (2012), McNamara (2008), Norrlof (2014), Otero-Iglesias and Steinberg (2012, 2013) and Stokes (2014).

${ }^{2}$ See, for example, Broz (1997), Henning (1994), Helleiner and Malkin (2012) and Katada (2008).
} 
economic capacity to run monetary policy effectively, and as political freedom from the government in its policy conduct. In this regard, it is of particular note that much research on CI tends to point to a decline in domestic monetary policy autonomy as one of the major related costs. ${ }^{3}$ This conventional view implies that, if it is to maximize its institutional interests, the central bank will likely oppose $\mathrm{CI}$ in order to maintain its monetary policy autonomy. However, as will be discussed below in great detail, one of the leading advocates of RMB internationalization (hereafter, RMBI) has been the People's Bank of China (hereafter, the PBC), ${ }^{4}$ China's central bank, and this poses a puzzle to observers. Meanwhile, the literature has seldom examined the impact of $\mathrm{CI}$ on the independence of the central bank, despite the political and economic significance of this impact, and this research offers an analysis of that important issue as well.

This study finds that, contrary to the conventional understanding, CI does not necessarily weaken the central bank's monetary policy autonomy, but rather tends to lead to its growing, especially during the early stages of the life cycle of CI, by inducing a shift to a flexible exchange rate system and also by helping to create better conditions for the effective operation of price-based monetary policy. This research also illustrates that CI tends to enhance the central bank's independence as well, by increasing foreign pressures favoring it and by reinforcing its monetary policy autonomy. Based upon these two findings, this study ultimately puts forward its central argument on the preferences of the central bank regarding CI: that, all other things being equal, a central bank with weak monetary policy autonomy and low independence is more likely to support the internationalization of its currency, particularly where it is willing to accept a flexible exchange rate. The empirical analysis validating these arguments focuses primarily on the case of RMBI and the PBC, given that this case offers a unique opportunity to observe closely how the central bank acts in the beginning stages of CI.

This research makes several significant theoretical and empirical contributions to the literature. Theoretically, it expands the list of major domestic political actors seen as involved in CI to include the central bank, thereby casting new light on the principal role of domestic politics in CI. It also leads us to reconsider the major consequences-in other words, the main benefits and costs — of CI, with relation in particular to monetary policy autonomy and central bank independence, and provides in addition a new perspective explaining why some emerging economies like China seek internationalizations of their currencies despite their weak economic and political conditions for it. Empirically, this study presents a systematic and comprehensive investigation of why the PBC has so actively supported RMBI, based upon close examination including interviews with senior PBC officials in the key positions related to RMBI, as well as upon examination of documents and papers in the local language.

The remaining part of this paper is organized as follows. After reviewing the literature on CI in general, and also on RMBI in particular, we outline our analytic framework and articulate our major arguments. Following this we provide empirical evidence to support

\footnotetext{
${ }^{3}$ See, for example, Broz (1997), Canzoneri et al. (2013), Chinn and Frankel (2007), Dobbs et al. (2009), Henning (1994), Kenen (2009) and McNamara (2008).

${ }^{4}$ The abbreviation PBC is the official one used by the People's Bank of China itself.
} 
these arguments, by conducting an in-depth analysis of the Chinese case. We then offer conclusions in the final section, discussing the generalizability of our arguments as well as our study’s major contributions.

\section{LONG NEGLECT OF THE CENTRAL BANK}

Most studies of CI analyze practical issues such as the futures of the dollar, the euro, the yen and the RMB as international currencies, and generally address two broad theoretical themes: CI's consequences, and its determinants. Studies of the consequences of CI mainly analyze the major economic and political benefits and costs of issuing an international currency, usually from the perspective of the issuing state. ${ }^{5}$ The primary benefits consist of international seigniorage, increased macroeconomic flexibility, decreased currency mismatch problems, growing business gains for domestic financial institutions, and strengthening of the country's international power. The chief costs include constraints on monetary policy autonomy, and declines in competitiveness in the export and importcompeting sectors. Additionally, some studies points to market-oriented financial reforms as another major consequence of CI, noting that deep and broad financial markets are necessary for making a currency more internationally attractive. ${ }^{6}$

Research on the determinants of CI meanwhile strives to identify the economic and political factors that affect it at the international and/or domestic levels. The major economic factors include the country's economic size, its shares in world trade and world finance, the level of its financial market development, and its monetary and fiscal policies. ${ }^{7}$ The political factors encompass its domestic institutions, sectoral interests, international power and foreign relations. ${ }^{8}$

These two areas of study — of the consequences of and the determinants of CI-are intertwined to some extent, as the consequences of a currency's internationalization affect who will benefit from it and thus support it and who will lose from it and therefore oppose it in the issuing country. There is in fact some research that explores the domestic politics of CI based upon its domestic distributional effects. Most of this, however, tends to focus primarily on the preferences of private interests such as financial institutions and nonfinancial corporations. ${ }^{9}$ Despite the principal position of the central bank in the monetary

\footnotetext{
${ }^{5}$ See, for example, Broz (1997), Cohen (1971, 1998, 2012a, 2015), Dobson and Masson (2009), Eichengreen (2011), Genberg (2010), Kenen (2009), Kirshner (1995, 2008), McNamara (2008) and Tavlas (1991). Notably, a recent paper on RMBI by Chey (2015) provides a 'demand-side study' of CI, by analyzing the benefits and the costs of using the RMB from the standpoint of a foreign country using it.

${ }^{6}$ See, for example, Helleiner and Malkin (2012).

${ }^{7}$ See Chinn and Frankel (2007, 2008), Eichengreen and Flandreau (2008, 2012), Helleiner (2008), Kenen (2002), Krugman (1984), McNamara (2008), Norrlof (2014), Otero-Iglesias and Steinberg (2012, 2013), Stokes (2014) and Tavlas and Ozeki (1992). Given that domestic financial market development is both a necessary condition for CI and one of its consequences, there is circular causation between these two issues. ${ }^{8}$ See Broz (1997), Chey (2013), Germain and Schwartz (2014), Helleiner (2008), Helleiner and Malkin (2012), Ly (2012), McNamara (2008), Momani (2008), Norrlof (2014), Otero-Iglesias and Steinberg (2013), Pittaluga and Seghezza (2012), Posen (2008), Stokes (2014) and Walter (2006).

${ }^{9}$ See, for example, Broz (1997), Helleiner and Malkin (2012), Henning (1994) and Katada (2008). While
} 
and financial system, even such domestic research on CI has seldom placed the central bank at the center of analysis.

To be sure, a few studies do deal with the central bank in their analyses of issues related to CI. One notable example is the research by C. Randall Henning (1994) on external monetary policies of the United States, Germany and Japan. This work examines CI as one element of external monetary policies, and treats central bank independence as a key independent variable explaining the differences in external monetary policies across the case countries. However, in this study central bank independence is neither a factor affected by CI nor one influencing central bank preferences regarding it, but a variable affecting the degree to which private-sector preferences (mainly over exchange rate policy) are translated into actual policy outcomes. Henning's study also focuses mainly on the negative impact of CI on monetary policy autonomy, and as a result has limitations in explaining any strong central bank support for CI. ${ }^{10}$ Meanwhile, J. Lawrence Broz’s (1997) research on the origin of the Federal Reserve addresses the Fed's creation, rather than its own preferences relative to dollar internationalization. Some studies such as Walter (2006) point to central bank independence as one of the political factors that may affect CI, but they hardly investigate the preferences regarding CI of the central bank itself.

Recently, the Chinese central bank, the PBC, has attracted some attention from those observing the advance of RMBI, as it has been one of RMBI's main advocates. The central goal of a majority of the studies of RMBI has in fact been to assess its feasibility. ${ }^{11}$ But there is some research tackling the Chinese authorities' motivations for pursuing RMBI, which generally points out the major ones as being a reduction in China's reliance on the dollar, the strengthening of its international status and influence, and the acceleration of its domestic financial reform. ${ }^{12}$ And, with particular connection to domestic financial reform, a few authors have touched on the PBC's intentions in supporting RMBI. They usually argue that the PBC wishes to achieve capital account liberalization or broader domestic financial reform under the guise of RMBI, which has strong nationalistic appeal. ${ }^{13}$

Our analysis in the present paper supports this account of the PBC's advocacy of RMBI to some extent, in that we will also show that the PBC seeks to pursue domestic financial reform by promoting RMBI. However, our study goes further than the domestic reform argument by complementing its notable shortcomings. Most of those holding this view offer only passing comments, rather than providing systematic analyses with solid evidence. And more importantly, they fail to explain why the PBC pushes for financial

Broz (1997) stresses the generalizability of private preferences, Helleiner and Malkin (2012) and Henning (1994) emphasize their context specificity.

10 The primary focus of Henning (1994) is actually exchange rate policy, and in particular the value of the currency and its stability.

11 See, for example, Chen and Cheung (2011), Chey (2013, 2015), Cohen (2012b, 2014, 2015), Dobson and Masson (2009), Ito (2010), Lee (2014), Subacchi (2013), Subramanian (2011) and Subramanian and Kessler (2012).

12 See, for example, Bowles and Wang (2013), Kirshner (2014), Mallaby and Wethington (2012), Yu (2014) and Zhang (2015). Meanwhile, drawing on theories in comparative capitalism, some studies such as McNally (2012, 2015) analyze the unique Chinese_or 'Sino-capitalist'_characteristics of China's policies for RMBI. ${ }^{13}$ See, for example, Bell and Feng (2013), Davis (2011), Feng (2012), Kroeber (2013), Lo (2013), Thornton (2012), Volz (2014), Yu (2014) and Zhang (2015). 
reform, which actually does not belong among its main responsibilities. In other words, they tend to see financial reform per se as the ultimate goal of the PBC, sometimes merely noting or assuming that its officials are the most liberal economists in the country. ${ }^{14}$ In contrast to this account, our study stresses that the fundamental goal of the PBC in its support of RMBI is to strengthen its own core institutional interests, of monetary policy autonomy and independence, rather than to merely achieve financial reform per se, while demonstrating how these two goals are connected with each other.

\section{CURRENCY INTERNATIONALIZATION AND THE CENTRAL BANK}

This section explains the analytic framework of this study, and articulates its major arguments.

\section{The analytic framework}

Our research does acknowledge, as the literature notes, that in promoting RMBI the Chinese authorities may have such policy goals as the lowering of China's dependence on the dollar, the heightening of its international clout and the accelerating of its domestic economic reforms, and that the PBC may share these national goals to some extent. It however stresses the need for analyzing how CI affects the central bank's own institutional interests, in order to reach a better understanding of its preferences in this regard. For the central bank is not an apolitical agency that always pursues the public interest only, but inherently a political actor that also holds, just like any other government agency, its own institutional interests and seeks to maximize them. ${ }^{15}$

With this in mind, this study addresses the impact of CI on the central bank's two core institutional interests among others: monetary policy autonomy and independence. Although the impact of CI on monetary policy autonomy has been frequently discussed in the literature, its impact on central bank independence has been rarely mentioned. Our study thus expands the list of major consequences of CI to encompass central bank independence. Further, while the literature tends to discuss the impacts of CI on monetary policy autonomy and on domestic financial reform separately, we emphasize their connection, and argue that monetary policy autonomy is affected by domestic financial reform induced by CI, as well as directly by CI itself.

\section{Monetary policy autonomy}

A majority of the studies of CI tend to indicate a decline in monetary policy autonomy as the first of its major costs, ${ }^{16}$ although some of them do also note an increase in

\footnotetext{
14 See, for example, Jiang (2014).

${ }^{15}$ For general reviews of central banks’ preferences, see Bowles and White (1994), Goodman (1991) and Fernandez-Albertos (2015). Maxfield (1997) also analyzes this in the developing country context.

${ }^{16}$ See, for example, Broz (1997), Canzoneri et al. (2013), Chinn and Frankel (2007), Cohen (2012a), Dobbs
} 
macroeconomic flexibility as one of its major benefits-which actually complicates the understanding of CI's effect on monetary policy autonomy. In detail, three distinct mechanisms through which CI constrains monetary policy autonomy have been pointed to. First, the central bank's ability to control the domestic money supply and interest rates may be limited, as foreign holdings of the currency may render the demand for it less stable and as the broadened scope for purchases and sales of the currency, by both residents and nonresidents, tends to result in increased capital flows into and from the country. Second, where foreign confidence in the currency's value weakens the central bank may need to compromise on its domestic policy goals-by adopting tighter monetary policy than otherwise-so as to prevent foreign selling off of the currency. This mechanism is related to the so-called Triffin dilemma, that the country issuing the key international currency has to supply it to the world, but its unlimited supply will then eventually erode confidence in the currency's value, exposing the country to a risk of foreigners abruptly liquidating or reducing their holdings of the currency. Finally, in running its monetary policy, the country issuing a consequential international currency is expected to assume greater responsibility for management of the overall world economy, rather than pursuing its own domestic objectives solely.

Such analyses of the negative effects of CI on monetary policy autonomy carry a significant implication concerning the central bank's preferences related to CI: since it is expected to hurt monetary policy autonomy, one of its core institutional interests, the central bank may be reluctant or opposed to its currency's internationalization. In fact, a good number of studies point to the reluctance of the Japanese and German authorities to encourage internationalizations of their currencies in the past, particularly during the 1960s through the 1980s, and explain this mainly by citing the aforementioned first or second mechanisms constraining monetary policy. ${ }^{17}$ Much research on RMBI also expresses concerns about its negative impacts on the PBC's monetary policy autonomy through these three mechanisms. ${ }^{18}$

In stark contrast to the Japanese and German cases, however, the PBC has been one of the most enthusiastic advocates of RMBI in China, as will be examined in detail below. And how can we explain this puzzle? In fact, a more rigorous analysis of the effects of CI on monetary policy autonomy suggests that the negative impacts are much more limited than conventionally thought, and that CI may even strengthen autonomy.

To begin with the first mechanism restraining monetary policy autonomy, the limitations on it due to foreign holdings of the currency and the increased ease of cross-border capital flows, the question of whether CI will actually reduce or increase monetary policy autonomy depends primarily on the type of the exchange rate regime. For in a strict sense the impact of CI on monetary policy autonomy has more to do with the rise in the degree of capital mobility, which tends to increase along with CI, rather than with CI per se (Chinn

et al. (2009), Henning (1994), Kenen (2009) and McNamara (2008).

${ }^{17}$ See, for example, Genberg (2010), Henning (1994), Iwami and Sato (1996) and Tavlas (1991).

${ }^{18}$ See, for example, Chen and Peng (2010), Gao (2010), Hai and Yao (2010), International Monetary Institute (2014), Xu and He (2015), Zhang (2015) and Zhang and Tao (2014). 
and Frankel, 2007; Genberg, 2010; Kenen, 2009). ${ }^{19}$ Thus, the impact of CI on monetary policy autonomy is in essence related to the so-called 'unholy trinity', the trilemma that a country can simultaneously achieve only two of the three policy objectives of a fixed (or stable) exchange rate, capital mobility and monetary policy autonomy. ${ }^{20}$ Under a fixed exchange rate, constraints on monetary policy autonomy due to CI do exist, but they disappear or at least decline where a country adopts a flexible exchange rate system, in other words where it is willing to endure a decrease in exchange rate stability (Chinn and Frankel, 2007; Genberg, 2010; Kenen, 2009). ${ }^{21}$

Japan and Germany in the 1960s and the early 1970s were in fact operating fixed exchange rates under the Bretton Woods system. And so their authorities' worries about loss of monetary policy autonomy due to internationalization of their currencies were plausible. Although Japan later moved to a floating exchange rate after the collapse of Bretton Woods, exchange rate stability, and particularly the avoidance of yen appreciation, remained one central concern of the Bank of Japan (BOJ) for quite some time, restraining it from supporting yen internationalization (Henning, 1994). But after the 1997 amendment of the Bank of Japan Act specified price stability as the BOJ's primary policy goal, formally eliminating its responsibility for exchange rate stability, the BOJ became more supportive of yen internationalization, perceiving that it would not constrain its monetary policy autonomy under a free floating exchange rate. ${ }^{22}$ For Germany, after the breakdown of Bretton Woods it belonged formally to the European fixed exchange rate systems - the socalled European 'snake', and subsequently the European Monetary System-until launch of the common euro currency. Under its commitment to these fixed exchange rate systems the Bundesbank remained reluctant concerning internationalization of the German mark, in order to avoid weakening its monetary policy autonomy (Henning, 1994).

As to the constraints on monetary policy due to concerns about dumping of the currency, the second mechanism limiting monetary policy autonomy, this risk is quite real. The sterling 'overhang' during the decades following World War II, which significantly constrained UK monetary policy, is one good example (Cohen, 2015; Eichengreen, 2008, 2011; Schenk, 2010). This risk persists even under a floating exchange rate, as any sudden vast selloff of a currency causes a drastic decline in its value that can seriously disrupt the economy. It should be stressed, however, that this risk tends to intensify in the later stages of the life cycle of an international currency, when that currency loses its market appeal. In the early stages of an international currency's life cycle-in other words when its internationalization is on rise - demand for the currency is growing, and the risk of its drastic liquidation is therefore not high (Chey, 2012, 2014; Cohen, 2012a, 2015; Helleiner and Malkin 2012). Moreover, in a phenomenon that Valéry Giscard d'Estaing, French Minister of Economy and Finance in the 1960s, once criticized as the 'exorbitant privilege'

\footnotetext{
${ }^{19}$ In fact, there do not appear to be any significant differences in monetary policy autonomy among the United States, the eurozone, the United Kingdom and Japan, even despite the substantial differences in the degrees of their currencies' internationalizations (Papaioannou and Portes, 2008: 70).

${ }^{20}$ This 'unholy trinity' is also frequently called the 'impossible trinity'.

${ }^{21}$ However, monetary policy autonomy in small open economies tends to be limited even under floating exchange rate regimes, due to their 'fear of floating' (Calvo and Reinhart, 2002).

${ }^{22}$ Author interview with senior BOJ official, November 17, 2014, Tokyo. See also Iwami and Sato (1996).
} 
of the United States (Eichengreen, 2011: 4), the state issuing a dominant international currency can finance its balance-of-payments deficits by printing its currency, insofar as foreigners are willing to hold it. And as a result its capacity to evade the effects of market discipline on its monetary policy strengthens when the internationalization of its currency is on the rise, meaning an increase in its monetary policy autonomy (Chey, 2012, 2014; Cohen, 2012a, 2015; Helleiner and Malkin, 2012).

With regard to the burdens of global responsibility on a state issuing a leading international currency, the third mechanism constraining monetary policy autonomy, history shows that irresponsible leaders are in practice not rare. The United States, for instance, has quite frequently not been a responsible issuer of the key international currency when its responsibility to the world has conflicted with its domestic priorities. It unilaterally abandoned the Bretton Woods system in 1971, and the Latin American debt crisis was also triggered by tight Fed monetary policy. The Fed has also adopted an extremely loose monetary policy since the GFC, despite strong complaints from emerging economies about the resulting huge amounts of capital flowing into them, which have increased their risks of financial instability and led them to eventual adoptions of capital controls. Although the state issuing a leading international currency is expected to assume responsibility for the world economy, this state, which is usually a dominant power during its time, does not in practice always fulfill that responsibility.

Our analysis has until now focused on the direct effects of CI on monetary policy autonomy. CI can however also affect monetary policy autonomy through its impacts on the domestic financial system, as it tends to influence a turn of that system in a more liberal and market-oriented direction. In detail, it is widely acknowledged that, for substantial internationalization of a currency, capital account liberalization is necessary in order to increase the convenience of the currency's use, in other words to reduce the transaction costs of that use. Capital account liberalization, in turn, necessitates certain domestic financial reforms, and two among others of them have significant connections to monetary policy autonomy.

First, capital account liberalization requires a shift to a flexible exchange rate system, as a country adopting a fixed exchange rate regime despite maintenance of an open capital account risks speculative capital attacks (Chey, 2012). As discussed above, under the 'unholy trinity' framework, if there is an open capital account in place domestic monetary policy autonomy tends to be amplified with the adoption of flexible exchange rates. And a drive for CI thus tends to reinforce monetary policy autonomy through facilitating the move to a flexible exchange rate system, although this does also mean that the economy must compromise and accept increased exchange rate volatility.

Second, capital account liberalization also tends to promote conditions necessary for effective operation of a price-based monetary policy, using interest rates as the primary monetary tool as is currently done in most advanced economies. For instance, capital account liberalization requires the liberalization of interest rates, a key condition for effective price-based monetary policy operation. If a country opens its capital account without liberalizing interest rates, this may generate a liquidity crisis as domestic depositors will likely move funds from the country to realize better profits (Chey, 2012). Also, the deepening and broadening of financial markets induced by CI strengthens the sensitivity of 
money balances to interest rates, and as a result boosts the effectiveness of price-based monetary policy (Kasman and Rodrigues, 1991; Liao and Tapsoba, 2014). ${ }^{23}$ The economics literature has indeed found empirical evidence suggesting that both the adoption of more flexible exchange rates and the liberalization of interest rates have improved monetary policy autonomy by enhancing monetary policy transmission (Kasman and Rodrigues, 1991; Liao and Tapsoba, 2014).

Whether such financial reforms induced by CI are benefits or costs to the overall economy depends upon the specific contexts of the domestic financial system, as Helleiner and Malkin (2012) note. A country that wishes to maintain a credit-based, tightly-regulated financial system, for instance, is likely to perceive such reforms as costs, and will therefore be reluctant concerning CI, as shown in the cases of Japan and Germany in the past (Helleiner and Malkin, 2012). Yet, if a country is trying to achieve a consequential degree of CI, such financial reforms are generally required. The low degrees of internationalization of the yen and German mark compared with that of the dollar are in fact frequently attributed to the relative underdevelopment of their financial markets vis-à-vis the deep and broad markets in the United States. ${ }^{24}$

To sum up, the argument stressing the negative impacts of CI on monetary policy autonomy tends to be oversimplified. Instead, the pursuit of a high level of CI is likely to have positive effects on monetary policy autonomy, by leading the economy to adopt a flexible exchange rate as well as by helping it to strengthen its conditions for effective price-based monetary policy operation. In addition, monetary policy autonomy tends to be reinforced during the early stages of the life cycle of CI, since market pressures on monetary policy tend to be weaker in those times although they do grow later. All of this suggest that, given the long life cycle of an international currency, ${ }^{25}$ a central bank with low monetary policy autonomy will likely support rather than oppose the internationalization of its currency, in expectations of the strengthening of its monetary policy autonomy and particularly where it is willing to accept a flexible exchange rate.

\section{Central bank independence}

Together with its monetary policy autonomy, independence from its government comprises another of the central bank's central institutional interests, as this reduces the government's interference in its policies, including not only monetary policy but also management of its financial and human resources, and, going further, strengthens its authority and profile in policymaking circles. Central banks do indeed tend to use their resources - such as their policy expertise, their information, and their links with financial and business leaders and international financial institutions - in order to promote or protect their independence (Bowles and White, 1994).

\footnotetext{
${ }^{23}$ The economics literature shows considerable evidence that financial integration helps overall financial market development, which Kose et al. (2009) refer to as the 'collateral benefits' of financial globalization.

${ }^{24}$ See, for example, Henning (1994).

${ }^{25}$ The internationalization of the dollar began in the early 1910s, and it is still the dominant international currency.
} 
In analyzing its consequences, the literature on CI has paid little attention to central bank independence. CI is however likely to have positive impacts on central bank independence through two channels. First, one of the most fundamental conditions of an international currency is the strong confidence of foreign users in that currency's future value, and this tends to require that the central bank be free from domestic political pressures. As mentioned above, some studies such as Walter (2006) indicate central bank independence to be one of the political factors that may affect CI. And indeed, the issuers of the key international currencies in modern history, both the Bank of England and the Fed, did both maintain strong political independence when their currencies began to rise internationally, although the degrees of their independence also fluctuated thereafter (Meltzer, 2003; Wood, 2005).

CI may also boost the independence of the central bank by promoting its monetary policy autonomy. For the independence of a central bank is ultimately affected by its performance in carrying out its monetary policy; where a central bank runs a successful monetary policy, its authority is likely to grow and its independence to be maintained or strengthened. Conversely, where its monetary policy is ineffective a central bank will be criticized for policy failure, and its independence may as a result be threatened and its authority within policymaking circles decline. And as analyzed earlier, CI is likely to improve the conditions for the central bank's success in monetary policy by strengthening its monetary policy autonomy. This will in consequence strengthen its independence as well.

These analyses of the impacts of CI on central bank independence lead us to anticipate that a central bank having low independence is likely to prefer internationalization of its currency, as a means of helping it achieve its institutional interests.

\section{The central argument}

Overall then, consolidating our analyses of the effects of CI on central bank monetary policy and independence, we can state our core argument in the present study as follows: that, ceteris paribus, where its monetary policy autonomy is constrained and/or its independence is low, and where it is also more willing to accept a flexible exchange rate, a central bank will be more likely to support the internationalization of its currency in order to promote its monetary policy autonomy and/or enhance its independence.

It should be stressed, however, that this statement does not necessarily mean that central banks with high degrees of monetary policy autonomy and independence are likely to oppose internationalization of their currencies. A more plausible expectation may be rather that such banks will be less interested in promoting it.

\section{RENMINBI INTERNATIONALIZATION AND THE PEOPLE'S BANK OF CHINA}

The present section provides empirical evidence in support of the theoretical arguments stated above, with a focus primarily on the case of RMBI and the PBC. 


\section{The PBC’s push for RMBI}

As analyzed by Helleiner and Malkin (2012), there have been few strong domestic private interests in China supportive of RMBI, with many rather being opposed to it. Instead, it is the $\mathrm{PBC}$ that has played the central role in promoting RMBI, through the leading of diverse policy initiatives, although the $\mathrm{PBC}$ has had to acquire Chinese government approval for them due to its status of subordination to the government.

To start with, the PBC itself first raised the issue of RMBI as a national agenda, even before the GFC that became the turning point for a sudden surge of widespread interest in RMBI in China (Yu, 2014). The PBC conducted research on the use of RMB in neighboring economies in as early as 2005, and one year later published an article (PBC Study Group on Renminbi Internationalization, 2006) arguing that the time had come for the promotion of RMBI, with an index included for measuring the degree of internationalization of a currency. The PBC also persuaded the State Council (China's central cabinet) to approve the offshore issuance of RMB bonds (so-called 'dim sum bonds'), despite resistance from powerful ministries such as the Ministry of Finance (MOF), which sought to retain its control over the bond markets.

After the outbreak of the GFC in 2008, Zhou Xiaochuan, the PBC Governor, published in March 2009 a reverberating essay calling for the creation of a supranational reserve currency, and implicitly suggested addition of the RMB to the special drawing right (SDR) — an international reserve asset created by the International Monetary Fund (IMF), with its value based on a basket of major international currencies (currently the dollar, the euro, the yen and the British pound) — which would help to enhance RMBI (Zhou, 2009). This essay appears to have led the Chinese leadership to endorse the idea of much larger international roles for the RMB, as shown by the fact that, one month after its publication, the State Council approved a plan suggested by the PBC to permit use of the RMB in crossborder trade settlement (Davis, 2011). A few months later, in November 2009, the PBC established its Monetary Policy Department (hereafter, MPD) II, and put it in charge of RMBI and exchange rate policy.

Since then the PBC has continued to lead a majority of the policy measures undertaken to promote RMBI. These include the establishments of the Renminbi Qualified Foreign Institutional Investor (RQFII) program (that allows foreign investors to invest in mainland bonds and equities using offshore RMB), of RMB clearing banks in foreign economies, of $\mathrm{RMB} /$ local currency swaps with foreign central banks, and of a cross-border RMB payment system (known as the China International Payment System). The PBC has also opened up the Chinese interbank bond market to foreign central banks, international financial organizations and sovereign wealth funds, and allowed non-public foreign financial institutions as well to raise RMB-denominated debt capital in China's bond market. Moreover, the PBC has strongly supported the plan for developing Shanghai into an international financial center by 2020, as well as the Shanghai-Hong Kong Stock Connect.

Largely owing to these deliberate policies by the PBC, RMBI has made remarkable progress in recent years. Approximately one-quarter of both China's trade and its overseas 
direct investment are now settled in the RMB. ${ }^{26}$ According to the Society for Worldwide Interbank Financial Telecommunication (SWIFT), the payment services provider, in August 2015 the RMB also became the fourth most popular currency used in cross-border payments, even overtaking the yen to trail only the dollar, the euro and the British pound. ${ }^{27}$

The question then is why has the PBC pushed so enthusiastically ahead with RMBI? What are the PBC's interests behind its drive for RMBI?

\section{Enhancement of monetary policy autonomy}

It should be stressed that the PBC's monetary policy autonomy has been significantly constrained by certain core elements of the current Chinese monetary and financial system. One such element is China's managed exchange rate regime. To keep the RMB's exchange rate stable at a desirable level even despite the country's huge current account surpluses, the PBC has had to intervene in the foreign exchange market to buy up foreign currency with RMB. ${ }^{28}$ And the PBC's monetary policy has as a result been significantly paralyzed. The bank has faced particular difficulties in raising interest rates, since doing so would put additional upward pressures on the exchange rate by attracting capital inflows (Feng, 2011b: 27; Volz, 2014: 116).

The huge accumulation of foreign exchange reserves resulting from the PBC's foreign exchange market interventions has further complicated the problem. The increased reserves have caused inflationary pressures in the Chinese economy due to the expanded money supply. ${ }^{29}$ The PBC has worked to absorb excess liquidity-in other words 'sterilized' its foreign exchange interventions - by issuance of PBC bills, as well as by increasing banks' reserve ratio requirements. And this sterilization policy has generated great costs to the PBC, worsening its balance sheet, as the interest rates on PBC bills tend to be higher than the rates the $\mathrm{PBC}$ receives on its holdings of the US Treasuries accounting for the majority of its reserves (Feng, 2011b: 27). Even worse, the PBC has also been subject to the risk of massive capital losses on its dollar-denominated reserve holdings in any case of dollar depreciation. In April 2011, in fact, on the day when Standard \& Poor's, one of the 'big three' credit rating agencies, placed a negative outlook on the US government's debt position, Governor Zhou remarked that the amount of China's reserves was 'really too much’ (Feng, 2011b: 26).

In addition, the scale of China's bond markets is still small, as the volume of Chinese government bonds amounts to only about 9.3 percent of M2. This underdevelopment of the Chinese bond markets has made it difficult for the PBC to use a price-based monetary policy, leading it to rely heavily on quantity-based policies such as reserve ratio requirements (International Monetary Institute, 2014: 138).

\footnotetext{
${ }^{26}$ It should be noted, however, that more than one-half of the country's RMB trade settlement is still done with Hong Kong, which is actually a part of China (PBC, 2015).

${ }^{27}$ Its share was still not high, however, amounting to 2.8 percent only.

${ }^{28}$ In the early 2010s the PBC used more than 90 percent of its base money issuance for this purpose (Feng, 2011b: 27).

${ }^{29}$ In June 2014 the volume of China’s reserves amounted to four trillion dollars.
} 
In this situation the PBC has had strong motivations to try to strengthen its monetary policy autonomy, and has expected that RMBI will help it to achieve this goal by leading to more market-oriented reforms of the current financial system. ${ }^{30}$ In detail, in order for RMBI to reach a substantial level, capital account liberalization is likely to be needed; and to liberalize the capital account without risking massive speculative capital flows and a domestic liquidity crisis, shifts to both a more flexible exchange rate and a more liberal financial system, particularly interest rate liberalization, should take place beforehand. And these two policy changes are critical elements that will reinforce the PBC's monetary policy autonomy.

Under a more flexible exchange rate regime, the need for PBC intervention in the foreign exchange market will decline, which will augment the bank's monetary policy autonomy. Moreover, RMBI fundamentally reduces Chinese reliance on the dollar, a root cause of the managed exchange rate system and resulting massive accumulation of dollar reserves, and this will also buttress PBC monetary policy autonomy. Meanwhile, the liberalization of interest rates will help the PBC to adopt a more price-based monetary policy framework, which will boost its monetary policy effectiveness. RMBI also helps the Chinese bond markets to develop, in line with the expanded use of RMB financial instruments, making it easier for the PBC's monetary policy to shift from its current quantity-based framework to a more price-based one. Governor Zhou has in fact noted that the key to improving the effectiveness of China's monetary policy lies not so much in the realm of monetary policy per se, but in wider market-oriented financial reforms including a further opening of the Chinese economy (Bell and Feng, 2013: 160-61).

The PBC has shown firm determination to achieve these policy changes, albeit not necessarily at a drastic speed, by calling for and leading them even before RMBI became a national agenda. Governor Zhou and his deputies initiated the 2005 exchange rate regime reform, which replaced the previous hard peg against the dollar with a managed floating system, under which the RMB was managed with reference to a basket of currencies and allowed to fluctuate within a narrow band around its daily reference rate (Bell and Feng, 2013). The upper and lower ranges of the RMB's daily fluctuations against the dollar were initially set at 0.3 percent, but gradually increased up to 2 percent. More recently, in August 2015, the PBC adopted a more market-oriented method for fixing the RMB reference rate, by revising the rate from a moving average of the past ten trading days to the previous day's closing rate in the interbank foreign exchange market, making the exchange rate system more flexible. This policy change was viewed by many market observers as driven by Chinese determination to get the RMB included in the SDR, which will likely boost RMBI. ${ }^{31}$ And the IMF has in fact called the new system a 'welcome step, as it should allow

\footnotetext{
${ }^{30}$ Author interview with senior official in MPD II, PBC, Beijing, July 17, 2015. See also Cheng (2014), Ma (2011) and Wang (2014).

31 This system change brought about a 1.9 percentage point devaluation of the RMB, its biggest one-day move since 1993, and that was followed by another 1.6 percent decline the following day. There is as a result a view that the change was aimed mainly at boosting Chinese exports, through RMB devaluation. However, the gap between onshore and offshore RMB exchange rates against the dollar declined dramatically after the change, supporting the argument that the main goal was to make the RMB exchange rate more market-sensitive (Hughes, 2015).
} 
market forces to have a greater role in determining the exchange rate' (Donnan, 2015) while also stating its belief that 'China can, and should, aim to achieve an effectively floating exchange-rate system within two to three years’ (Zhu, 2015). The PBC has gradually liberalized interest rates as well. It removed the deposit rate floor and the lending rate ceiling in 2004, and then the lending rate floor in 2013. A deposit insurance scheme, a precondition for full deposit rate liberalization, was launched in May 2015, and three months after that the ceiling on long-term deposit rates was lifted as well. ${ }^{32}$

It should be emphasized that the PBC does indeed perceive the adverse impacts of RMBI on its monetary policy autonomy as likely to be minimal. ${ }^{33}$ And this perception seems plausible, given its strong determination to shift toward a more flexible exchange rate system that will reduce its policy constraints stemming from the 'unholy trinity'. The PBC also notes that the concentration of the RMB's international use on real economic sectors such as trade and overseas direct investment, which limits the room for speculative capital movements, along with the small size of the offshore RMB markets, minimize the negative effects of RMBI on its monetary policy autonomy. ${ }^{34}$ In response to a question concerning the possibility of RMBI complicating the PBC's monetary policy, a senior official in MPD II at the PBC stressed that the Fed had paid little attention to the impacts on its monetary policy of the dollar's international uses, and that use of the dollar internationally had led to few constraints on Fed monetary policy, before remarking that 'the same will be the case for China when the RMB ascends to become an international currency'. 35

It is in addition worth noting that RMBI is a politically useful strategy for promoting the PBC's monetary policy autonomy, as it helps to some extent to attenuate domestic opposition to the required reforms. In fact, the PBC's efforts to reform the Chinese financial system have frequently been impeded by strong opposition from those having vested interests in the Chinese traditional development model, the main pillars of which are credit controls and export-led growth, as such reforms imply that model's abandonment. These opponents include the state-owned banks and state-owned enterprises and exporters, as well as powerful government bodies that have been responsible for those sectors such as the MOF, the Ministry of Commerce (MOC) and the National Development and Reform Commission (NDRC) (Bell and Feng, 2013). RMBI helps to weaken such domestic opposition to the reforms, as to an extent it serves the interests of some of these traditional reform opponents. RMBI may for example reduce the exchange risks and operational costs of Chinese exporters. And in this regard, many Chinese exporters are in fact willing to offer discounts to foreign importers, of around 3 to 5 percent, if they use RMB for trade settlement (Chey, 2015: 8). The MOC, which has been responsible for international trade and thus preferred reserve accumulation, also appears to have come to favor RMBI recently

\footnotetext{
${ }^{32}$ For more on the history of China's financial reforms, see Bell and Feng (2013) and Steinberg (2014).

${ }^{33}$ Author interview with senior official in MPD II, PBC, Beijing, July 17, 2015. Recent, as well as earlier, reports by PBC officials in its MPD II share this view. See Ma (2011), PBC Research Bureau (2004) and Wu and Ning (2014).

${ }^{34}$ Author interview with senior official in MPD II, PBC, Beijing, July 17, 2015. In fact, there are strong signs showing a long-term convergence of interest rates across the onshore and offshore RMB markets.

${ }^{35}$ Author interview with senior official in MPD II, PBC, Beijing, July 17, 2015.
} 
(Bowles and Wang, 2013: 1377-78). State-owned banks, which have benefited from interest rate controls, may also gain from RMBI, since it may expand their business opportunities. At the same time, as RMBI has become a national policy goal, perceived widely as a 'Chinese dream', explicit opposition to it has grown more difficult. ${ }^{36}$ There has in fact been little apparent opposition from the major government bodies to RMBI per se as a fundamental objective, although they have expressed differing ideas of how to achieve it. $^{37}$

\section{Strengthening of independence}

RMBI also helps the PBC to defend and, going further, strengthen its independence. The PBC is not yet an independent central bank. According to the 1995 Law of the People's Republic of China on the PBC, which granted it the status of the central bank in the national legislation and the mandate to formulate and implement monetary policy and financial supervision, the PBC formally operates 'under the leadership of the State Council'. Major policy moves on interest rates and exchange rate policy must be approved by the State Council (Bell and Feng, 2013: 9). This having been said, compared with the past, when the PBC was a puppet agency of the central state and a mere body for monetary policy implementation serving the fiscal needs of the government and state-owned businesses, the PBC's independence - and in particular, its operational independence-has grown considerably stronger, especially since the mid-1990s. ${ }^{38}$ The PBC has successfully established itself as a substantial force within Chinese macroeconomic policymaking circles, where it plays a key role in shaping policy options and providing advice (Bell and Feng, 2013).

This rise in the PBC's independence has been attributable largely to the expansion in the Chinese leadership's dependence on the PBC. The PBC's expertise in modern central banking, its institutional capacity in monetary policy, and its establishment of a credible policy record have made it indispensable to the central government in the government's efforts to maintain sustainable growth. In other words, the role of the PBC as a 'problem solver' has helped it to increase its authority within the hierarchy of Chinese policymaking (Bell and Feng, 2013; Shih, 2007). Its successful management of monetary policy thus directly affects the PBC's political clout and independence within the Chinese government, and PBC officials' career advancements are also linked to the bank's institutional performance. Any failure by the PBC to operate its monetary policy effectively may lead to declines in its authority and influence, and in its independence in turn (Bell and Feng, 2013;

\footnotetext{
${ }^{36}$ Author interview with Liu Dongmin, Deputy Director, Department of International Finance, Institute of World Economics and Politics, Chinese Academy of Social Sciences, Tokyo, November 17, 2014.

${ }^{37}$ Author interview with senior official in MPD II, PBC, Beijing, July 17, 2015. See also Feng (2011a: 67). According to our PBC interviewee, the 'loudest dissenting' voices come from some academics in the Chinese Academy of Social Sciences, a prestigious Chinese think tank, who stress the need for a neat policy sequencing of capital account liberalization and RMBI.

38 Author interview with senior official in MPD II, PBC, Beijing, July 17, 2015. On the evolution of the PBC’s independence, see Bell and Feng (2013) and Chin (2013).
} 
Steinberg, 2014). By the same token, any further rise in the PBC’s authority and independence will depend largely upon its success in monetary policy management.

In this situation, due to the constraints on the PBC's monetary policy there has been considerable domestic criticism of the PBC, as incapable of holding domestic inflation and asset bubbles in check, and this threatens the bank's authority within the Chinese government. For example, in an unusually scathing remark in late 2011, Luo Jiwei, then Chair of China Investment Corporation and incumbent finance minister, blamed the PBC for mismanaging China's monetary affairs by 'acting like central banks in small economies', which tend to hoard voluminous foreign reserves and retain little monetary policy autonomy (Luo, 2011). This criticism brings to mind a similar view among mainland economists that, as a large economy, China should seek greater 'policy space' through CI, or at least currency regionalization, which would improve the central bank's monetary policy autonomy and effectiveness. ${ }^{39}$ The PBC has also been criticized substantially within China for its alleged mismanagement of the nation's foreign reserves (Bell and Feng, 2013: 255; Steinberg, 2014).

Therefore, the strengthening of its monetary policy autonomy through RMBI is directly related to the PBC's independence as well. It is noteworthy in this regard that the involvements in exchange rate and foreign reserve policies of other powerful players such as the MOF and the NDRC have grown in recent years, as they have encroached on the PBC's authority in these areas (Bell and Feng, 2013: 52, 91; Jiang, 2014: 163). This situation may have increased the PBC's determination to defend its independence through RMBI, which is likely to strengthen its monetary policy autonomy.

RMBI moreover places the Chinese leadership under direct pressure to increase the PBC's independence, as the international community is aware that under government control of the monetary authority there is a critical potential risk of monetary policy exploitation for the government's own political goals. Indeed, many foreign and domestic observers have called for strengthening of the PBC's independence to ensure successful RMBI, emphasizing the need to improve the credibility of China's economic and legal systems. ${ }^{40}$ And in fact, according to some insiders in Chinese policy circles, top leaders have considered granting the PBC formal independence, which would make it the first government agency in Chinese history to have been awarded autonomy from the government (Feng, 2013: 50).

To be sure, the PBC does not itself expect to achieve full independence from the government, owing in part to its broad policy responsibilities, which go beyond monetary policy and require it to work together with other government agencies, as well as to its weak manpower. ${ }^{41}$ Nonetheless, it does regard monetary policy independence as 'what it could obtain in reality'. ${ }^{42}$

\footnotetext{
${ }^{39}$ See, for example, Zhang (2014) and Li (2011).

${ }^{40}$ See, for example, Eichengreen and Kawai (2014) and Huang, Wang and Fan (2014).

${ }^{41}$ Author interview with senior official in MPD II, PBC, Beijing, July 17, 2015. For example, the PBC is also responsible for development of the Chinese credit information and credit ratings systems.

${ }^{42}$ Author interview with senior official in MPD II, PBC, Beijing, July 17, 2015.
} 


\section{CONCLUSION}

Despite the crucial position of the central bank in the economy, the literature has paid little attention to that institution's role in the process of CI. This study has attempted to fill this critical gap by analyzing the preferences of the central bank regarding CI. In contrast to the conventional emphasis on the negative impacts of CI on domestic monetary policy, we find that CI is in fact likely to strengthen the central bank's monetary policy autonomy, especially in its early stages. It can in addition be expected to promote central bank independence from its government. A central bank with low monetary policy autonomy and independence, and with a willingness as well to accept a flexible exchange rate, is thus more likely to support CI, which it can use as an effective means for strengthening them. Our analysis of the PBC and RMBI has strongly supported these arguments.

Are these arguments generalizable, going beyond the Chinese case? Although systematic testing against a large number of other cases is outside the scope of this paper, we provide now a preliminary discussion in this regard by briefly addressing the cases of the major international currencies in modern history. Firstly, the cases of the British pound in the nineteenth century and the dollar in the early twentieth century — that is, when those currencies rose as leading international currencies - do not challenge our arguments, as their situations were not comparable with that of today's RMB. In those times the issuing countries had adopted the gold standard, under which the primary monetary policy goals of their central banks were to maintain the gold parities of their currencies, with domestic monetary policy autonomy in the contemporary sense seldom a major central bank concern (Eichengreen, 2008). Secondly, the cases of Japan and Germany during the 1960s to the 1980s, when they were reluctant to promote internationalizations of the yen and the German mark, do not challenge our arguments either. As discussed previously, those two countries operated fixed exchange rates under Bretton Woods, and even after that system's collapse remained reluctant to accept free floating, putting great emphasis on exchange rate stability instead. Moreover, the independence of the Bundesbank is well known. And while the BOJ's independence at that time is in contrast often perceived to have not been high, there are studies that argue the opposite. ${ }^{43}$

Thirdly, the more recent cases of the BOJ, the European Central Bank (ECB) and the Federal Reserve, all of which are generally assessed as having relatively decent monetary policy autonomy and independence, appear to be in line with our argument that such central banks are unlikely to be eager to promote internationalizations of their currencies. Although the BOJ has not been opposed to internationalization of the yen any longer since the late 1990s, when it became more willing to tolerate free floating, its support for yen internationalization has been lukewarm, in contrast to the case of the PBC. The ECB, meanwhile, has since its inauguration in 1998 taken a quite neutral position toward internationalization of the euro. And the Fed has not expressed any significant concerns about the dollar's leading international currency status, even despite its extremely loose monetary policies since the GFC, which have been widely indicated as likely, in the long

\footnotetext{
${ }^{43}$ See, for example, Parkin (1986).
} 
run at least, to significantly tarnish the dollar's international status. ${ }^{44}$ Finally, the cases of other emerging economies appear to offer more direct support for our central argument. In addition to China, some other emerging economies such as India and Russia aspire to internationalize their currencies, and they tend to have central banks with weak monetary policy effectiveness and/or low independence. ${ }^{45}$ This rudimentary observation of other countries' cases suggests that the generalizability of our arguments is likely high, and it will thus be worth testing them in a more systematic manner in future studies.

We conclude by highlighting the major contributions of this study to the literature. First of all, this research calls attention to the need to factor in the central bank in the study of CI, as a primary political actor that can affect the political dynamics surrounding CI. To our knowledge this is one of the first studies providing a systematic political economy analysis of this subject, and it can thus be expected to lay a significant foundation for future study. Related to this first point, the present study therefore ultimately stresses the importance of domestic politics in CI, in contrast to the majority of the studies of CI, which have been led mainly by economists and have as a result focused mainly on the domestic economic conditions of the issuing states. Although there are a few political economy studies addressing the domestic politics of CI, their number is still small, and further development of analysis of the domestic politics involved is certainly needed.

This study leads us to reconsider the consequences - the benefits and costs-of CI as well. In particular, it newly highlights the positive impacts of CI on monetary policy autonomy - both its direct ones, and its indirect ones through facilitation of domestic financial reform - as well as on central bank independence. In addition, the analysis in this research shows that a consequential degree of $\mathrm{CI}$ is likely to ultimately require a shift of the economy to a more liberal and market-oriented system. Whether this will benefit or hurt the economy depends largely on political economic specificities in the individual countries concerned. Those that are unwilling to bear the costs are reluctant to actively pursue internationalizations of their currencies, as shown in the cases of Japan and Germany in the past. The PBC is in contrast determined to undertake market-oriented reform. But how the PBC preference will be received in the Chinese policymaking process will ultimately be affected by the broad domestic politics surrounding RMBI, encompassing other government institutions and private interests. This issue is beyond the scope of the present study, but the growing, albeit gradual, liberalization of the Chinese financial system over the past decade, and the recent drastic advance in RMBI, may imply a consensus between Chinese leaders and the PBC, on the future policy direction at least, if not necessarily on the speed of the requisite reforms associated with it.

Going beyond mere nationalistic accounts, this study also opens a new way of understanding why some emerging economies engage in the daunting task of

\footnotetext{
${ }^{44}$ The Annual Reports between 2008 and 2014 of the Federal Reserve Board—which contain the bi-annual Monetary Policy Reports and the minutes of all Federal Open Market Committee meetings during the yearhave rarely mentioned the dollar's international roles, which implies that the issue did not enter significantly into the Fed's deliberations during this period.

${ }^{45}$ The independence of the Reserve Bank of India remains at the lowest level in the world (Dincer and Eichengreen, 2014). Meanwhile, the monetary policy of the Central Bank of Russia has been substantially criticized in that country in recent years (Johnson, 2013).
} 
internationalizing their currencies, even though their economic and political conditions have usually not reached the levels required for successful CI. In fact, in contrast to the cases of the past emergences of the British pound and the dollar as the leading international currencies, which were strongly backed by those countries' powerful financial interests (Broz, 1997; Eichengreen, 2011), the support of CI from domestic private interests in emerging economies tends not to be strong. ${ }^{46}$ The findings in this paper offer an account of why some of those countries nonetheless pursue internationalization of their currencies, which requires considerable expenditures from their only limited resources. Lastly, although by no means least importantly, this study offers an in-depth empirical analysis of the PBC's motives behind its vigorous support for RMBI, by illustrating how it actually perceives the expected impacts of RMBI on its monetary policy autonomy and independence.

\section{REFERENCES}

Bell, S. and Feng, H. (2013) The Rise of the People's Bank of China: The Politics of Institutional Change, Cambridge, MA: Harvard University Press.

Bowles, P. and Wang, B. (2008) 'The Rocky Road Ahead: China, the US and the Future of the Dollar', Review of International Political Economy, 15(3): 335-53. 2013. 'Renminbi Internationalization: A Journey to Where?', Development and Change, 44(6): 1363-85.

Bowles, P. and White, G. (1994) 'Central Bank Independence: A Political Economy Approach', The Journal of Development Studies, 31(2): 235-64.

Broz, J. L. (1997) The International Origins of the Federal Reserve System, Ithaca, NY: Cornell University Press.

Calvo, G. A. and Reinhart, C. M. (2002) 'Fear of Floating', The Quarterly Journal of Economics, 117(2): 379-408.

Canzoneri, M., Cumby, R., Diba, B. and Lopez-Salido, D. (2013) 'Key Currency Status: An Exorbitant Privilege and an Extraordinary Risk', Journal of International Money and Finance, 37(October): 371-93.

Chen, H. and Peng. W. (2010) 'The Potential of the Renminbi as an International Currency', in W. Peng and C. Shu (eds) Currency Internationalization: Global Experiences and Implications for the Renminbi, London: Palgrave Macmillan.

Chen, X. and Cheung, Y-W. (2011) 'Renminbi Going Global', China \& World Economy, 19(2): 1-18.

Cheng, S. (2014) Renminbi Guoji Hua Zhi Lu [The road to renminbi internationalization], (in Chinese) Beijing: China CITIC Press.

Chey, H-K. (2012) 'Theories of International Currencies and the Future of the World Monetary Order', International Studies Review, 14(1): 51-77.

\footnotetext{
${ }^{46}$ The weak support of CI from private interests in emerging economies might be attributable to their creditbased and tightly-regulated financial systems, the weak global competitiveness of their financial institutions, and so on.
} 
(2013) 'Can the Renminbi Rise as a Global Currency? The Political Economy of Currency Internationalization', Asian Survey, 53(2): 348-68.

(2014) 'The Political Economy of Currency Internationalization', in T. Oatley and W.

K. Winecoff (eds) Handbook of the International Political Economy of Monetary

Relations, Cheltenham and Northampton: Edward Elgar Publishing.

(2015) 'Renminbi in Ordinary Economies: A Demand-Side Study of Currency

Globalization', China \& World Economy, 23(3): 1-21.

Chin, G. T. (2013) 'Understanding Currency Policy and Central Banking in China', The Journal of Asian Studies, 72(3): 519-38.

Chinn, M. and Frankel, J. A. (2007) 'Will the Euro Eventually Surpass the Dollar as Leading International Reserve Currency?', in R. H. Clarida (ed) G7 Current Account Imbalances: Sustainability and Adjustment, Chicago, Ill: University of Chicago Press. (2008) 'Why the Euro Will Rival the Dollar', International Finance, 11(1): 49-73.

Cohen, B. J. (1971) The Future of Sterling as an International Currency, London: Macmillan. (1998) The Geography of Money, Ithaca, NY: Cornell University Press. (2009) 'Dollar Dominance, Euro Aspirations: Recipe for Discord?', Journal of Common Market Studies, 47(4): 741-66.

(2012a) 'The Benefits and Costs of an International Currency: Getting the Calculus Right', Open Economies Review, 23(1): 13-31.

(2012b) 'The Yuan Tomorrow? Evaluating China's Internationalisation Strategy', New Political Economy, 17(3): 361-71.

(2013) 'Currency and State Power', in M. Finnemore and J. Goldstein (eds) Back to Basics: State Power in a Contemporary World, Oxford: Oxford University Press. (2014) 'Will History Repeat Itself? Lessons for the Yuan', ADBI Working Paper Series No. 453, Tokyo: Asian Development Bank Institute. (2015) Currency Power: Understanding Monetary Rivalry, Princeton, NJ: Princeton University Press.

Cohen, B. J. and Benney, T. (2014) 'What Does the International Currency System Really Look Like?', Review of International Political Economy, 21(5): 1017-41.

Davis, B. (2011) 'Were China's Leaders Conned?', The Wall Street Journal, June 2.

Dincer, N. N. and Eichengreen, B. (2014) 'Central Bank Transparency and Independence: Updates and New Measures', International Journal of Central Banking, March: 189-253.

Dobbs, R., Skilling, D., Hu, W., Lund, S., Manyika, J. and Roxburgh, C. (2009) 'An Exorbitant Privilege? Implications of Reserve Currencies for Competitiveness', Discussion Paper, McKinsey Global Institute.

Dobson, W. and Masson, P. R. (2009) 'Will the Renminbi Become a World Currency?', China Economic Review, 20(1): 124-35.

Donnan, S. (2015) 'IMF Gives Cautious Approval to China's New Currency Regime', Financial Times, August 12.

Eichengreen, B. (2008) Globalizing Capital: A History of the International Monetary System, Princeton, NJ: Princeton University Press. 
(2011) Exorbitant Privilege: The Rise and Fall of the Dollar and the Future of the International Monetary System, Oxford: Oxford University Press.

Eichengreen, B. and Flandreau, M. (2008) 'The Rise and Fall of the Dollar, or When Did the Dollar Replace Sterling as the Leading Reserve Currency?', CEPR Discussion Paper No. 6869, London: Center for Economic Policy Research. (2012) 'The Federal Reserve, the Bank of England, and the Rise of the Dollar as an International Currency, 1914-1939', Open Economies Review, 23(1): 57-87.

Eichengreen, B. and Kawai, M. (2014) 'Issues for Renminbi Internationalization: An Overview', ADBI Working Paper No. 454, Tokyo: Asian Development Bank Institute.

Feng, H. (2011a) 'Beijing's Second Thought', Central Banking, 22(2): 64-68. (2011b) 'The Three-Trillion-Dollar Question', Central Banking, 21(4): 26-30. (2012) 'The Beginning of the End?', Central Banking, 23(1): 43-47. (2013) 'The Next "Mr RMB"?', Central Banking, 23(3): 45-50.

Fernandez-Albertos, J. (2015) 'The Politics of Central Bank Independence', Annual Review of Political Science, 18: 217-37.

Gao, H. (2010) 'Internationalization of the Renminbi and Its Implications for Monetary Policy', in W. Peng and C. Shu (eds) Curency Internationalization: Global Experiences and Implications for the Renminbi, London: Palgrave Macmillan.

Genberg, H. (2010) 'The Calculus of International Currency Use', Central Banking, 20(3): 63-68.

Germain, R. and Schwartz, H. (2014) 'The Political Economy of Failure: The Euro as an International Currency', Review of International Political Economy, 21(5): 1095122.

Goodman, J. B. (1991) 'The Politics of Central Bank Independence', Comparative Politics, 23(4): 329-49.

Hai, W. and Yao, H. (2010) 'Pros and Cons of International Use of the RMB for China', in W. Peng and C. Shu (eds) Currency Internationalization: Global Experiences and Implications for the Renminbi, London: Palgrave Macmillan.

Helleiner, E. (2008) 'Political Determinants of International Currencies: What Future for the US Dollar?', Review of International Political Economy, 15(3): 354-78.

Helleiner, E. and Kirshner, J. (eds) (2009) The Future of the Dollar, Ithaca, NY and London: Cornell University Press. (eds) (2014) The Great Wall of Money: Power and Politics in China's International Monetary Relations, Ithaca, NY and London: Cornell University Press.

Helleiner, E. and Malkin, A. (2012) 'Sectoral Interests and Global Money: Renminbi, Dollars and the Domestic Foundations of International Currency Policy', Open Economies Review, 23(1): 33-55.

Henning, C. R. (1994) Currencies and Politics in the United States, Germany, and Japan, Washington, DC: Institute for International Economics.

Huang, Y., Wang, D. and Fan, G. (2014) 'Paths to a Reserve Currency: Internationalization of the Renminbi and Its Implications', ADBI Working Paper Series No. 482, Tokyo: Asian Development Bank Institute. 
Hughes, J. (2015) 'Renminbi Outlook a Puzzle for Investors', Financial Times, London, October 8.

International Monetary Institute (Renmin University of China) (2014) The Internationalization of the Renminbi, London and New York: Routledge.

Ito, T. (2010) 'China as Number One: How about the Renminbi?', Asian Economic Policy Review, 5(2): 249-76.

Iwami, T. and Sato, K. (1996) 'The Internationalization of the Yen: With an Emphasis on East Asia', International Journal of Social Economics, 23(10/11): 192-208.

Jiang, Y. (2014) 'The Limits of China's Monetary Diplomacy', in E. Helleiner and J. Kirshner (eds) The Great Wall of Money: Power and Politics in China's International Monetary Relations, Ithaca, NY and London: Cornell University Press.

Johnson, J. (2008) 'Forbidden Fruit: Russia's Uneasy Relationship with the US Dollar', Review of International Political Economy, 15(3): 379-98. (2013) 'The Russian Federation: International Monetary Reform and Currency Internationalization', The BRICS and Asia, Currency Internationalization and International Monetary Reform Paper No. 4, Ontario: Asian Development Bank, Centre for International Governance Innovation, and Hong Kong Institute for Monetary Research.

Katada, S. N. (2008) 'From a Supporter to a Challenger? Japan's Currency Leadership in Dollar-dominated East Asia', Review of International Political Economy, 15(3): 399-417.

Kasman, B. and Rodrigues, A. P. (1991) 'Financial Liberalization and Monetary Control in Japan', FRBNY Quarterly Review, Autumn: 28-46.

Kenen, P. B. (2002) 'The Euro versus the Dollar: Will There Be a Struggle for Dominance?', Journal of Policy Modeling, 24(4): 307-14. (2009) 'Currency Internationalization: An Overview', BIS Research Paper, Basel: Bank for International Settlements.

Kirshner, J. (1995) Currency and Coercion: The Political Economy of International Monetary Power, Princeton, NJ: Princeton University Press. (2008) 'Dollar Primacy and American Power: What's at Stake?', Review of International Political Economy, 15(3): 418-38. (2014) 'Regional Hegemony and an Emerging RMB Zone', in E. Helleiner and J. Kirshner (eds) The Great Wall of Money: Power and Politics in China's International Monetary Relations, Ithaca, NY and London: Cornell University Press.

Kose, M. A., Prasad, E., Rogoff, K. and Wei, S-J. (2009) 'Financial Globalization: A Reappraisal', IMF Staff Papers 56(1): 8-62.

Kroeber, A. (2013) 'China's Global Currency: Lever for Financial Reform', Monograph Series No. 3, Beijing: Brookings-Tsinghua Center for Public Policy.

Krugman, P. (1984) 'The International Role of the Dollar: Theory and Prospect', in J. Bilson and R. Marston (eds) Exchange Rate Theory and Practice, Chicago, Ill: University of Chicago Press. 
Lee, J-W. (2014) 'Will the Renminbi Emerge as an International Reserve Currency?', The World Economy, 37(1): 42-62.

Li, C. (2011) Renminbi Guyu Hua Wenti Yanjiu [The study of the renminbi’s regionalization], (in Chinese) Beijing: Zhongguo Jinrong Chubanshe.

Li, F. (2015) 'China in Talks to Include Yuan in IMF Basket, PBOC Official Says', Bloomberg News, March 12.

Liao, S. and McDowell, D. E. (2015) 'Redback Rising: China's Bilateral Swap Agreements and Renminbi Internationalization', International Studies Quarterly, 59(3): 401-22.

Liao, W. and Tapsoba, S. J-A. (2014) 'China's Monetary Policy and Interest Rate Liberalization: Lessons from International Experiences', IMF Working Paper WP/14/75, Washington, DC: International Monetary Fund.

Lo, C. (2013) The Renminbi Rises: Myth, Hypes and Realities of RMB Internationalisation and Reforms in the Post-Crisis World, New York: Palgrave MacMillan.

Luo, J. (ed) (2011) 'Zhongguo Xuyao Jixu Shenhua Gaige De Liu Xiang Zhidu' [Six necessary moves to further reform China's economic system], (in Chinese) Comparative Studies, 57; accessed at http://magazine.caixin.com/2011-1214/100337863.html, April 15, 2015.

Ly, M. (2012) 'Special Drawing Rights, the Dollar, and the Institutionalist Approach to Reserve Currency Status', Review of International Political Economy, 19(2): 34162.

Ma, J. (2011) 'Renminbi Lian Shichang Fazhan Dui Jingnei Huobei He Jinrong De Yingxiang' [The impacts of offshore renminbi market development on domestic monetary and financial policies], (in Chinese) International Financing, no. 5: 5357.

Mallaby, S. and Wethington, O. (2012) 'The Future of the Yuan: China's Struggle to Internationalize Its Currency', Foreign Affairs, 91(1): 135-46.

Maxfield, S. (1997) Gatekeepers of Growth: The International Political Economy of Central Banking in Developing Countries, Princeton, NJ: Princeton University Press.

McNally, C. A. (2012) 'Sino-Capitalism: China's Reemergence and the International Political Economy', World Politics, 64(4): 741-76. (2015) 'The Political Economic Logic of RMB Internationalization: A Study in Sinocapitalism', International Politics, 52(6): 704-23.

McNamara, K. R. (2008) 'A Rivalry in the Making? The Euro and International Monetary Power', Review of International Political Economy, 15(3): 439-59.

Meltzer, A. H. (2003) A History of the Federal Reserve (Volume 1, 1913-1951), Chicago, Ill and London: University of Chicago Press.

Momani, B. (2008) 'Gulf Cooperation Council Oil Exporters and the Future of the Dollar', New Political Economy, 13(3): 293-314.

Norrlof, C. (2014) 'Dollar Hegemony: A Power Analysis', Review of International Political Economy, 21(5): 1042-70.

Otero-Iglesias, M. and Steinberg, F. (2012) 'Is the Dollar Becoming a Negotiated Currency? Evidence from Emerging Markets', New Political Economy, 18(3): 30936. 
(2013) 'Reframining the Euro vs. Dollar Debate through the Perceptions of Financial Elites in Key Dollar-Holding Countries', Review of International Political Economy, 20(1): 180-214.

Papaioannou, E. and Portes, R. (2008) 'Costs and Benefits of Running an International Currency', Economic Papers 348, Brussels: European Commission.

Parkin, M. (1986) 'Domestic Monetary Institutions and Deficits', in J. M. Buchanan, C. K. Rowley and R. D. Tollison (eds) Deficits, New York: Blackwell.

PBC (People's Bank of China) (2015) 'Renminbi Guojihua Baogo' [A report on renminbi internationalization], (in Chinese) Beijing, June.

PBC Research Bureau (2004) 'Gang Ao Diqu Renminbi Yewu Fazhan He Youguan Qingsuan Anpai' [Renminbi business development and clearing arrangements of Hong Kong and Macau], (in Chinese) Jinrong Yanjiu Baogao [Financial Research Report] 9(27): 1-8.

PBC Study Group on Renminbi Internationalization (2006) 'Renminbi Guojihua De Shiji, Tujing Ji Qi Celue' [The timing, path, and strategies of RMB internationalization], (in Chinese) China Finance, 5: 12-13.

Pittaluga, G. B. and Seghezza, E. (2012) 'Euro vs Dollar: An Improbable Threat', Open Economies Review, 23, no. 1: 89-108.

Posen, A. S. (2008) 'Why the Euro Will Not Rival the Dollar', International Finance, 11(1): 75-100.

Schenk, C. (2010) The Decline of Sterling: Managing the Retreat of an International Currency 1945-1992, Cambridge: Cambridge University Press.

Shih, V. (2007) 'Partial Reform Equilibrium, Chinese Style: Political Incentives and Reform Stagnation in Chinese Financial Policies', Comparative Political Studies, 40(10): 1238-62.

Steinberg, D. A. (2014) 'Why Has China Accumulated Such Large Foreign Reserves?', in E. Helleiner and J. Kirshner (eds) The Great Wall of Money: Power and Politics in China's International Monetary Relations, Ithaca, NY and London: Cornell University Press.

Stokes, D. (2014) 'Achilles' Deal: Dollar Decline and US Grand Strategy after the Crisis', Review of International Political Economy, 21(5): 1071-94.

Subacchi, P. (2013) 'Expanding Beyond Borders: The Yen and the Yuan', ADBI Working Paper Series No. 450, Tokyo: Asian Development Bank Institute.

Subramanian, A. (2011) Eclipse: Living in the Shadow of China's Economic Dominance, Washington, DC: Peterson Institute for International Economics.

Subramanian, A. and Kessler, M. (2012) 'The Renminbi Bloc Is Here: Asia Down, Rest of the World to Go?', Working Paper WP 12-19, Washington, DC: Peterson Institute for International Economics.

Tavlas, G. S. (1991) 'On the International Use of Currencies: The Case of the Deutsche Mark', Essays in International Finance No. 181, Princeton, N.J.: Princeton University.

Tavlas, G. S. and Ozeki, Y. (1992) 'The Internationalization of Currencies: An Appraisal of the Japanese Yen', IMF Occasional Paper No. 90, Washington, DC: International Monetary Fund. 
Thornton, A. (2012) 'Anaemic Ascent: Why China's Currency Is Far from Going Global', Sydney: Lowy Institute for International Policy.

Volz, U. (2014) 'All Politics Is Local: The Renminbi's Prospects as a Future Global Currency', in L. E. Armijo and S. N. Katada (eds) The Financial Statecraft of Emerging Powers: Shield and Sword in Asia and Latin America, Hampshire: Palgrave Macmillan.

Walter, A. (2006) 'Domestic Sources of International Monetary Leadership', in D. M. Andrews (ed) International Monetary Power, Ithaca, NY: Cornell University Press.

Wang, X. (2014) 'Renminbi Guoji Hua Xia De Huobi Zhengce Nanti' [Monetary policy challenges under renminbi internationalization] (in Chinese) The Chinese Banker, 3: 31-32.

Wood, J. H. (2005) A History of Central Banking in Great Britain and the United States, Cambridge: Cambridge University Press.

Wu, G. and Ning, Y. (2014) 'Lian Shichang Fazhan Dui Benguo Huobi Zhengce De Yingxiang: Wenxian Zongshu' [Influence of offshore market development on domestic monetary policy: A literature review], (in Chinese) PBC Working Paper No. 8, Beijing: People's Bank of China.

$\mathrm{Xu}, \mathrm{Q}$. and He, F. (2015) 'The Influence of RMB Internationalization on the Chinese Economy: Theory and Policy', CIGI Papers No. 58, Ontario: Center for International Governance Innovation.

Yu, Y. (2014) 'How Far Can Renminbi Internationalization Go?', ADBI Working Paper Series No. 461, Tokyo: Asian Development Bank Institute.

Zhang, J. (2014) 'Wanshan Woguo Caizheng Huobi Zhengce Caozuo De Ruogan Jianyi' [Some suggestions to improve the conducts of China's fiscal and monetary policies], (in Chinese) China Economic Times, May 27.

Zhang, L. and Tao, K. (2014) 'The Benefits and Costs of Renminbi Internationalization', ADBI Working Paper Series No. 481, Tokyo: Asian Development Bank Institute.

Zhang, M. (2015) 'Internationalization of the Renminbi: Developments, Problems and Influences', CIGI New Thinking and the New 20 Series Paper No. 2, Ontario: Center for International Governance Innovation.

Zhou, X. (2009) 'Reform the International Monetary System', People's Bank of China; accesed at http://www.bis.org/review/r090402c.pdf, May 5, 2010.

Zhu, J. (2015) 'China Devalues Currency in SDR Push', FinanceAsia, Hong Kong, August 11. 